\title{
ANALISIS PENGARUH KETEBALAN PLAT BAJA KARBON RENDAH DAN LAMA PENEKANAN PADA PENGELASAN TITIK (SPOT WELDING) TERHADAP NILAI KEKUATAN TARIK
}

\author{
Eko Nugroho', Untung Surya Dharma², Sodik Karuniawan³ \\ Jurusan Teknik Mesin, Universitas Muhammadiyah Metro \\ Jl. Ki Hajar Dewantara No. 116 Metro, Lampung, Indonesia \\ Email: exonugros@yahoo.co.id ${ }^{1}$, untungsdh@yahoo.co.id ${ }^{2}$, \\ sodikkaruniawan647@gmail.com ${ }^{3}$
}

\begin{abstract}
Abstrak
Penggunaan bahan yang standar dan tenaga ahli dalam bidang pengelasan pun menjadi daya tarik tersendiri bagi seorang peneliti untuk mengetahui apa saja yang dibutuhkan dalam pemilihan bahan, teknik pengelasan dan jenis sambungannya. Saat ini pengelasan seolah menjadi tren karena kelebihannya dibandingkan jenis sambungan lainya seperti sambungan baut dan paku keling.Pengelasan adalah proses mencairkan sebagian logam induk dengan tujuan menyambung logam dengan atau tanpa tekanan dan logam pengisi untuk menghasilkan sambungan yang terus menerus. Las titik banyak digunakan di industri besar seperti industri mobil, industri motor dan lain sebagainya. Industri mobil biasanya menggunakan las titik untuk pengerjaan karoseri bodi mobil atau rangka. Pengelasan titik memiliki peranan sangat penting sebagai proses penyambungan dalam industri otomotif, dan setiap kendaraan mengandung 2000 - 5000 lasan titik. Kualitas dan kekuatan lasan titik sangat penting terhadap perancangan umur dan keamanan dari kendaraan. Lap joint adalah salah satu jenis sambungan las yang ada yaitu jenis sambungan tumpuk, dimana kedua benda kerja sejajar satu sama lain dengan catatan salah satu ujung dari kedua benda kerja tersebut berada pada tingkat yang sama. Tujuan dari penelitian ini adalah untuk mengetahui kekuatan tarik dan lama tekan terhadap ketebalan plat yang paling optimal untuk pembebanan tarik. Pengelasan ini menggunakan baja karbon rendah ST 41 dan dengan menggunakan variasi ketebalan plat 0,6 $\mathrm{mm}, 0,8 \mathrm{~mm}$ dan $1 \mathrm{~mm}$ dengan lama tekan 1 detik, 2 detik dan 3 detik. Pengujian yang dilakukan adalah peengujian tarik menggunakan mesin UTM (Ultimate Testing Machine). Pada hasil pengujian didapat hasil kekuatan tarik dari masing - masing spesimen, dan terjadi penurunan nilai kekuatan tarik. Untuk kekuatan tarik terbesar rata-rata yang didapat adalah $67,69 \mathrm{~N} / \mathrm{mm}^{2}$ pada ketebalan plat 0,6 mm dengan lama tekan 3 detik.
\end{abstract}

Kata Kunci: Lap Joint, Pengelasan, Las Titik, Baja Karbon Rendah, Kekuatan Tarik.

\section{PENDAHULUAN}

Las dalam bidang konstruksi sangat luas penggunaannya meliputi konstruksi jembatan, perkapalan, industri karoseri dan sebagainya. Disamping untuk konstruksi, las juga dapat untuk mengelas cacat logam pada hasil pengecoran logam, mempertebal logam yang mengalami aus [1]. Secara sederhana dapat diartikan bahwa pengelasan merupakan proses penyambungan dua buah logam sampai titik rekristalisasi logam, baik menggunakan bahan tambah maupun tidak dan menggunakan energi panas sebagai pencair bahan yang dilas.

Berdasarkan definisi dari Deutche Industrie Normen (DIN) las adalah ikatan metalurgi pada sambungan logam atau logam paduan yang dilaksanakan dalam keadaan lumer atau cair. Penyambungan dua buah logam menjadi satu dilakukan dengan jalan pemanasan atau pelumeran, dimana kedua ujung logam yang akan disambung dibuat lumer atau dilelehkan dengan busur nyala atau panas yang didapat dari busur nyala listrik (gas pembakar) 
sehingga kedua ujung atau bidang logam merupakan bidang masa yang kuat dan tidak mudah dipisahkan [1]. Paling tidak saat ini terdapat sekitar 40 jenis pengelasan, dari seluruh jenis pengelasan tersebut hanya dua jenis yang paling populer di Indonesia yaitu pengelasan dengan menggunakan Las busur atau Las listrik (Shielded Metal Arc Welding/SMAW) dan Las karbit (Oxy Acetylene Welding/OAW).

Las titik (Spot Welding) adalah salah satu metode pengelasan yang prinsip kerjanya menggunakan arus listrik untuk menyambung plat logam. Proses pengelasannya yaitu dengan menjepit pelat menggunakan elektroda khusus. Siklus pengelasannya yaitu dengan memberikan tekanan pada pelat kemudian mengalirkan arus listrik dalam jumlah yang besar. Akibat besarnya arus listrik yang diberikan, maka bagian plat yang ditekan dan diberi arus akan memanas dan meleleh, tekanan elektroda yang diberikan pada plat akan dilepas sesaat setelah arus dialirkan agar plat yang dilas dapat menempel dengan sempurna.

Las titik banyak digunakan di industri besar seperti industri mobil, industri motor dan lain sebagainya. Industri mobil biasanya menggunakan las titik untuk pengerjaan karoseri body mobil atau rangka. Pengelasan titik memiliki peranan sangat penting sebagai proses penyambungan dalam industri otomotif, dan setiap kendaraan mengandung 2000 5000 lasan titik. Kualitas dan kekuatan lasan titik sangat penting terhadap perancangan umur dan keamanan dari kendaraan. Prosesnya yang mudah, ekonomis, dan cepat merupakan beberapa keuntungan dari proses pengelasan titik [1]. Proses pengerjaan las ini lebih cepat dan lebih rapi hasilnya dibandingkan dengan menggunakan las asetelin dan las busur listrik karena las yang dihasilkan tidak mengandung terak las.

Walaupun demikian proses pengerjaan las ini membutuhkan keahlian untuk mengerjakannya. Lama penekanan pada waktu proses pengerjaan akan menentukan hasil las serta kekuatan las yang diinginkan. Pelaksanaan atau penggunaan las titik tergantung pada 4 hal, diantaranya yaitu arus pengelasan, tekanan las titik, waktu tekan dan diameter permukaan elektroda [1]. Ditinjau dari segi metalurgi, penggunaan variabel las titik yang tidak tepat akan mengakibatkan perubahan yang tidak terencana dalam logam. Sehingga logam akan mengalami kerusakan dalam bentuk patah, retak, perubahan bentuk atau perubahan sifat mekanisnya yang mengakibatkan hasil pengelasan tidak dapat optimal.

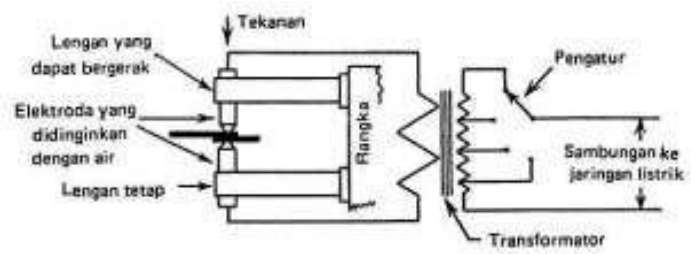

Gambar 1. Skema mesin las titik [1].

Berdasarkan pemaparan diatas, peneliti melakukan analisa beberapa parameter pengelasan yaitu ketebalan material dan waktu penekanan pada saat proses pengelasan sebagai variabel tidak tetap pada material plat dari bahan baja karbon rendah dengan tegangan dan arus sebagai variabel tetap, terhadap nilai kekuatan tarik sambungan las titik tersebut. Dengan demikian diharapkan penelitian ini akan diketahui kondisi optimal dan sambungan yang paling baik.

\section{METODE PENELITIAN}

\section{Bahan Penelitian}

Material yang digunakan untuk pross pengujian adalah plat baja karbon rendah ST 41 dengan ketebalan 0,6 mm, $0,8 \mathrm{~mm}$ dan $1 \mathrm{~mm}$.

Tabel 1. Komposisi kimia baja karbon rendah ST 41 [2].

\begin{tabular}{|c|c|c|c|c|c|c|}
\hline Material & $\begin{array}{c}\text { Besi } \\
(\mathrm{Fe})\end{array}$ & $\begin{array}{c}\text { Mangan } \\
(\mathrm{Mn})\end{array}$ & $\begin{array}{c}\text { Karbon } \\
(\mathrm{C})\end{array}$ & $\begin{array}{c}\text { Silikon } \\
(\mathrm{Si})\end{array}$ & $\begin{array}{c}\text { Fosfor } \\
(\mathrm{P})\end{array}$ & $\begin{array}{c}\text { Belerang } \\
(\mathrm{S})\end{array}$ \\
\hline ST 41 & $\begin{array}{c}98,98 \\
5 \%\end{array}$ & $0,6 \%$ & $0.1 \%$ & $0,25 \%$ & $0,03 \%$ & $0,035 \%$ \\
\hline
\end{tabular}




\section{Proses Pengelasan}

Pada penelitian ini dilakukan proses pengelasan material plat baja karbon rendah dengan metode las titik (spot welding) dan jenis sambungan yang digunakan lap joint dengan variasi lama tekan 1 detik, 2 detik dan 3 detik. Pelaksanaan pengelasan dilakukan di Lab. Teknik Fabrikasi Logam SMKN 1 Seputih Agung, Kab. Lampung Tengah, Lampung dan pengujian dilakukan di Lab. Pengujian Teknik Sipil Universitas Bandar Lampung.

\section{Proses Pengujian}

Pengujian yang dilakukan dalam penelitian ini adalah pengujian tarik. Pengujian ini dilakukan untuk mengetahui kekuatan geser hasil pengelasan titik pada logam baja karbon rendah. Pada pengujian ini dilakukan dengan menggunakan 18 spesimen. Adapun penentuan dimensi specimen uji mengacu sesuai dengan standar JIS Z 3139.

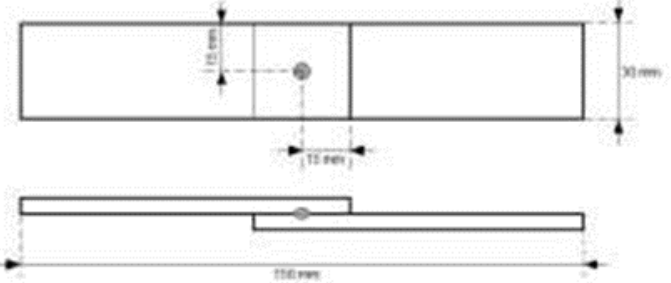

Gambar 2. Dimensi benda uji standar JIS Z 3139 [3].

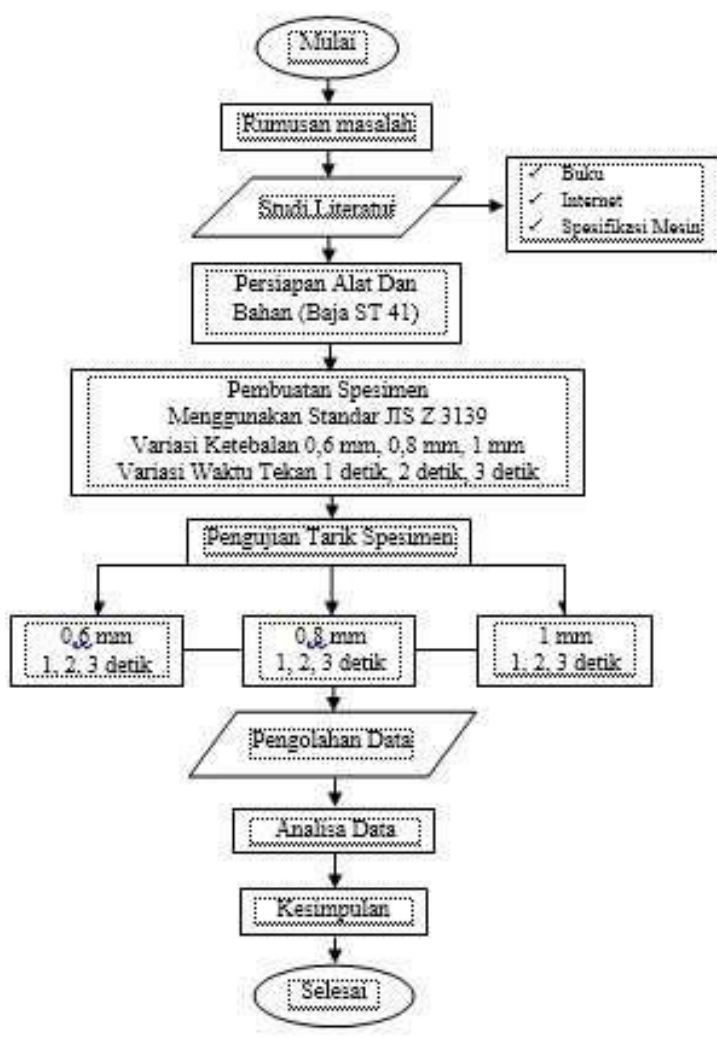

Gambar 3. Diagram alir penelitian

\section{HASIL DAN PEMBAHASAN}

Pada tahapan pengujian ini menghasilkan data, yang akan dianalisa dan kemudian diambil suatu kesimpulan. Pengujian yang dilakukan adalah pengujian tarik yang dilaksanakan di Lab. Pengujian Teknik Sipil Universitas Bandar Lampung menggunakan mesin Comp. Serv Hidraulik UTM (Universal Testing Machine). Hasil pengujian yang telah didapat dimasukkan kedalam tabel dan grafik, untuk dibandingkan dan diambil kesimpulan sehingga dapat diketahui variabel mana yang lebih optimal. Berdasarkan hasil dari pengujian didapatkan hasil beban tarik (max force), kekuatan tarik (ultimate strength), kekuatan luluh (yield strength) dan regangan (elongitas). 


\section{Sambungan Las Titik dengan Ketebalan Plat 0,6 mm.}

Tabel 2. Hasil pengujian tarik plat dengan tebal 0,6 mm [4].

\begin{tabular}{|c|c|c|c|c|c|}
\hline $\begin{array}{c}\text { Jenis } \\
\text { Bahan }\end{array}$ & $\begin{array}{c}\text { Lama } \\
\text { Tekan } \\
(\mathbf{s})\end{array}$ & $\begin{array}{c}\text { Beban } \\
\text { Tarik } \\
\text { Maksimun } \\
(\mathbf{N})\end{array}$ & $\begin{array}{c}\text { Tegangan } \\
\text { Tarik } \\
\left(\mathbf{N} / \mathbf{m m}^{2}\right)\end{array}$ & $\begin{array}{c}\text { Tegangan } \\
\text { Luluh } \\
\left(\mathbf{N} / \mathbf{m m}^{2}\right)\end{array}$ & $\begin{array}{c}\text { Regangan } \\
(\%)\end{array}$ \\
\hline \multirow{2}{*}{$\begin{array}{c}\text { Baja } \\
\text { Karbon } \\
\text { Rendah } \\
\text { ST41 }\end{array}$} & 1 & 528,30 & 28,36 & 11,47 & 0,98 \\
\cline { 2 - 6 } & 3 & 589,20 & 32,73 & 21,60 & 0,99 \\
\cline { 2 - 6 } & 1218,50 & 67,69 & 6,68 & 1,61 \\
\hline
\end{tabular}

Untuk lebih jelas dapat dilihat pada grafik dibawah yang akan menerangkan pengaruh waktu tekan terhadap tegangan tarik (ultimate), tegangan luluh (yield) dan regangan (elongation).

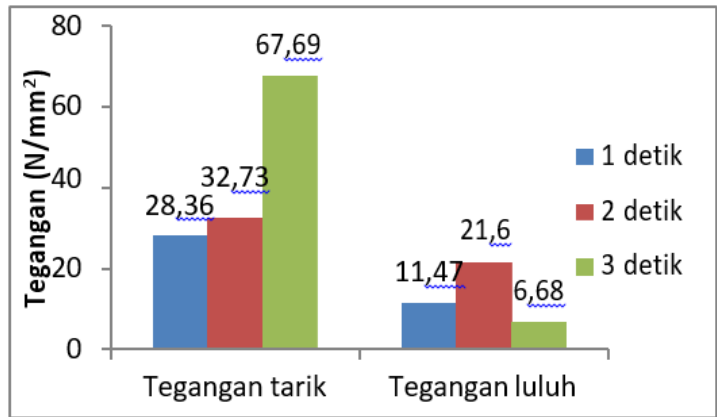

Gambar 4. Grafik tegangan tarik (ultimate) dan tegangan luluh (yield) sambungan plat $0,6 \mathrm{~mm}$.

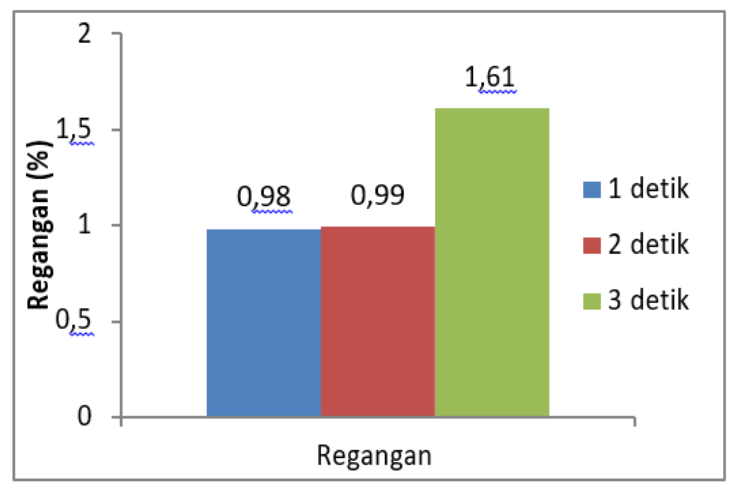

Gambar 5. Grafik regangan (elongation) sambungan plat $0,6 \mathrm{~mm}$.
Sambungan Las Titik dengan Ketebalan Plat $0,8 \mathrm{~mm}$.

Tabel 3. Hasil pengujian tarik plat dengan tebal $0,8 \mathrm{~mm}$ [4].

\begin{tabular}{|c|c|c|c|c|c|}
\hline \multirow{2}{*}{$\begin{array}{c}\text { Jenis } \\
\text { Bahan }\end{array}$} & $\begin{array}{c}\text { Lama } \\
\text { Tekan } \\
(\mathbf{s})\end{array}$ & $\begin{array}{c}\text { Beban } \\
\text { Tarik } \\
\text { Maksimun } \\
(\mathbf{N})\end{array}$ & $\begin{array}{c}\text { Tegangan } \\
\text { Tarik } \\
\left(\mathbf{N} / \mathbf{m m}^{2}\right)\end{array}$ & $\begin{array}{c}\text { Tegangan } \\
\text { Luluh } \\
\left(\mathbf{N} / \mathbf{m m}^{2}\right)\end{array}$ & $\begin{array}{c}\text { Regangan } \\
(\%)\end{array}$ \\
\hline \multirow{2}{*}{$\begin{array}{c}\text { Baja } \\
\text { Karbon } \\
\text { Rendah } \\
\text { ST41 }\end{array}$} & 2 & 746,65 & 31,12 & 27,95 & 0,67 \\
\cline { 2 - 6 } & 1 & 672,05 & 28,00 & 17,18 & 0,84 \\
\cline { 2 - 6 } & 3 & 930,60 & 38,78 & 36,58 & 1,05 \\
\hline
\end{tabular}

Untuk lebih jelas dapat dilihat pada grafik dibawah yang akan menerangkan pengaruh waktu tekan terhadap tegangan tarik (ultimate), tegangan luluh (yield) dan regangan (elongation).

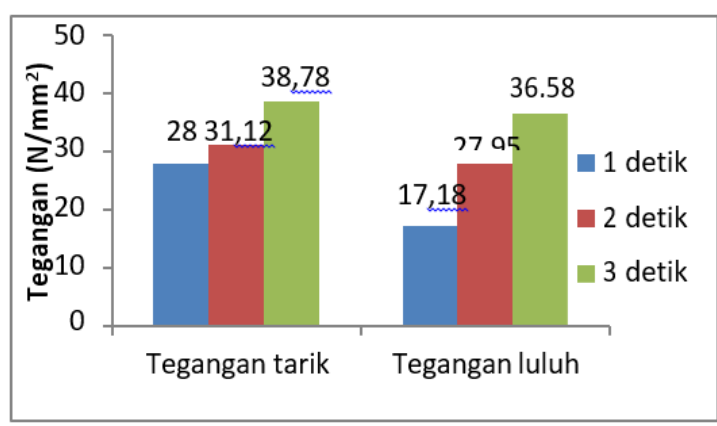

Gambar 6. Grafik tegangan tarik (ultimate) dan tegangan luluh (yield) sambungan plat $0,8 \mathrm{~mm}$.

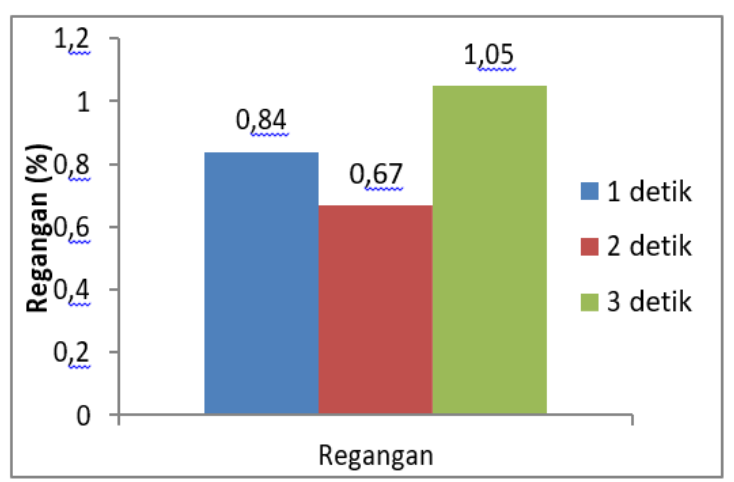

Gambar 7. Grafik regangan (elongation) sambungan plat $0,8 \mathrm{~mm}$. 


\section{Sambungan Las Titik dengan Ketebalan Plat 1 mm.}

Tabel 4. Hasil pengujian tarik plat dengan tebal $1 \mathrm{~mm}$ [4].

\begin{tabular}{|c|c|c|c|c|c|}
\hline $\begin{array}{c}\text { Jenis } \\
\text { Bahan }\end{array}$ & $\begin{array}{c}\text { Lama } \\
\text { Tekan } \\
(\mathbf{s})\end{array}$ & $\begin{array}{c}\text { Beban } \\
\text { Tarik } \\
\text { Maksimun } \\
(\mathbf{N})\end{array}$ & $\begin{array}{c}\text { Tegangan } \\
\text { Tarik } \\
\left(\mathbf{N} / \mathbf{m m}^{2}\right)\end{array}$ & $\begin{array}{c}\text { Tegangan } \\
\text { Luluh } \\
\left(\mathbf{N} / \mathbf{m m}^{2}\right)\end{array}$ & $\begin{array}{c}\text { Regangan } \\
(\%)\end{array}$ \\
\hline \multirow{2}{*}{$\begin{array}{c}\text { Baja } \\
\text { Karbon } \\
\text { Rendah } \\
\text { ST41 }\end{array}$} & 1 & 433,10 & 13,79 & 4,16 & 0,72 \\
\cline { 2 - 6 } & 3 & 344,42 & $11,4 /$ & 4,54 & 0,44 \\
\cline { 2 - 6 } & 337,35 & 11,25 & 5,08 & 0,37 \\
\hline
\end{tabular}

Untuk lebih jelas dapat dilihat pada grafik dibawah yang akan menerangkan pengaruh waktu tekan terhadap tegangan tarik (ultimate), tegangan luluh (yield) dan regangan (elongation).

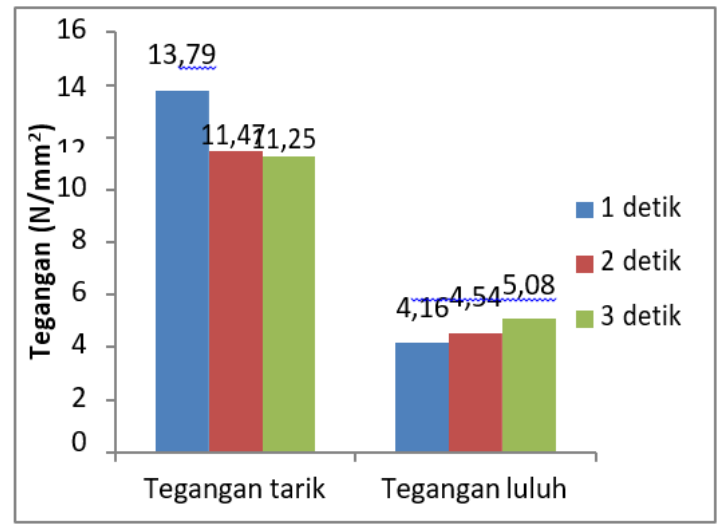

Gambar 8. Grafik tegangan tarik (ultimate) dan tegangan luluh (yield) sambungan plat $1 \mathrm{~mm}$.

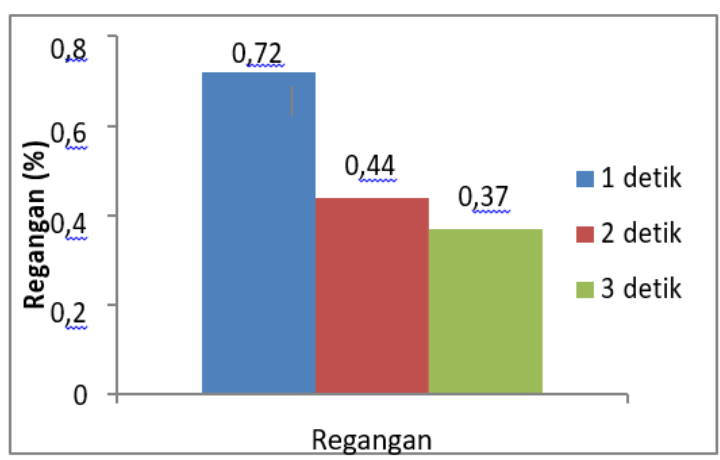

Gambar 9. Grafik regangan (elongation) sambungan 10 plat $1 \mathrm{~mm}$.
Pengaruh Ketebalan Plat dan Waktu Tekan Terhadap Tegangan Tarik (Ultimate)

Untuk hubungan antara tegangan tarik dengan tebal plat dan waktu tekan dapat dilihat pada grafik di bawah ini:

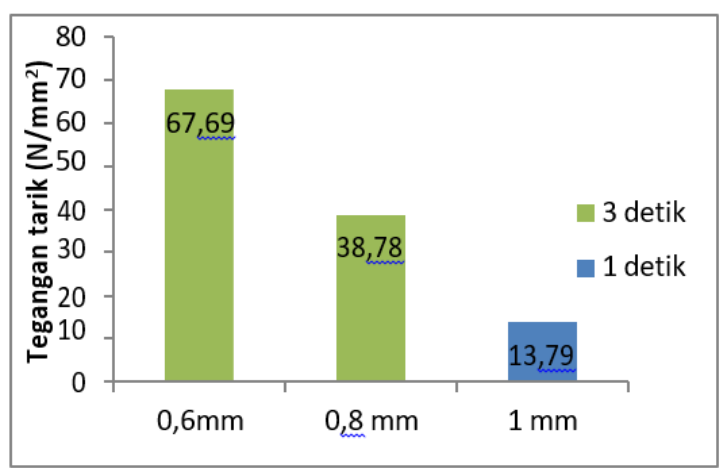

Gambar 10. Grafik pengaruh tebal plat dan waktu tekan terhadap tegangan tarik

(ultimate) sambungan las titik.

Pada grafik tersebut diatas dapat terlihat bahwa nilai kekuatan tarik tertinggi untuk plat dengan tebal $0,6 \mathrm{~mm}$ terdapat pada waktu tekan 3 detik dengan nilai $67,69 \mathrm{~N} / \mathrm{mm}^{2}$, plat dengan tebal 0,8 $\mathrm{mm}$ terdapat pada waktu tekan 3 detik dengan nilai $38,78 \mathrm{~N} / \mathrm{mm}^{2}$ dan plat dengan tebal $1 \mathrm{~mm}$ terdapat pada waktu tekan 1 detik dengan nilai $13,79 \mathrm{~N} / \mathrm{mm}^{2}$. Nilai-nilai kekuatan tarik tersebut menunjukkan bahwa untuk plat dengan tebal $1 \mathrm{~mm}$ berbanding terbalik dengan plat dengan tebal $0,6 \mathrm{~mm}$ dan $0,8 \mathrm{~mm}$. Tegangan tarik (ultimate) adalah tegangan maksimum yang mampu ditahan oleh sebuah material bahan atau logam ketika diregangkan atau ditarik, sebelum material tersebut patah dan digunakan untuk mencari nilai keelastisan suatu material.

Pengaruh Ketebalan Plat dan Waktu Tekan Terhadap Tegangan Luluh (Yield) Untuk hubungan antara tegangan luluh dengan tebal plat dan waktu tekan dapat dilihat pada grafik di bawah ini: 


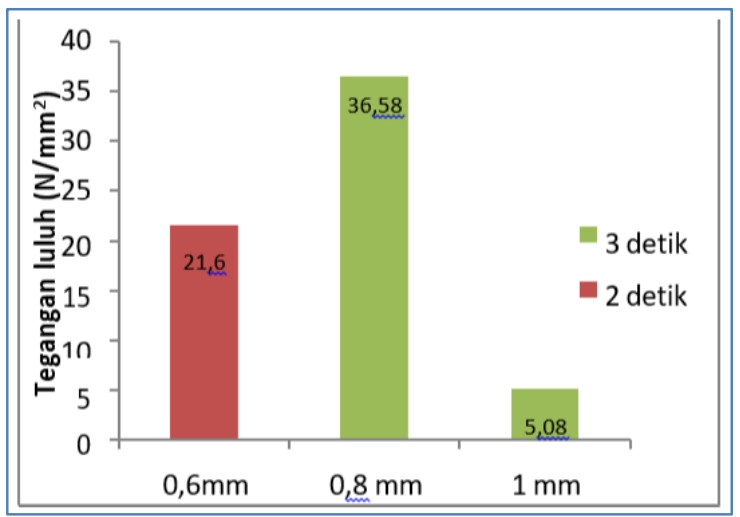

Gambar 11. Grafik pengaruh tebal plat dan waktu tekan terhadap tegangan luluh (yield) sambungan las titik.

Dari grafik tersebut diatas dapat diketahui bahwa nilai tegangan luluh yang paling tinggi untuk plat dengan tebal 0,6 mm adalah waktu tekan 2 detik dengan nilai tegangan $21,6 \mathrm{~N} / \mathrm{mm}^{2}$, untuk plat dengan tebal $0,8 \mathrm{~mm}$ adalah waktu tekan 3 detik dengan nilai tegangan $36,58 \mathrm{~N} / \mathrm{mm}^{2}$ dan untuk plat dengan tebal $1 \mathrm{~mm}$ adalah waktu tekan 3 detik dengan nilai tegangan $5,08 \mathrm{~N} / \mathrm{mm}^{2}$. Nilai-nilai kekuatan luluh tersebut menunjukkan bahwa untuk plat dengan tebal $0,6 \mathrm{~mm}$ nilai kekuatan luluhnya berbeda dengan plat dengan tebal 0,8 $\mathrm{mm}$ dan $1 \mathrm{~mm}$.Tegangan luluh merupakan tegangan yang dibutuhkan untuk menghasilkan sejumlah kecil deformasi plastis yang ditetapkan. Perlu diketahui bahwa nilai luluh adalah titik awal sebuah material bahan atau logam mulai terdeformasi secara plastis, dengan kata lain adalah nilai minimum yang dibutuhkan untuk menghasilkan deformasi plastis.

\section{Pengaruh Ketebalan Plat dan Waktu Tekan Terhadap Regangan (Elongation)}

Untuk hubungan antara regangan dengan tebal plat dan waktu tekan dapat dilihat pada grafik di bawah ini:

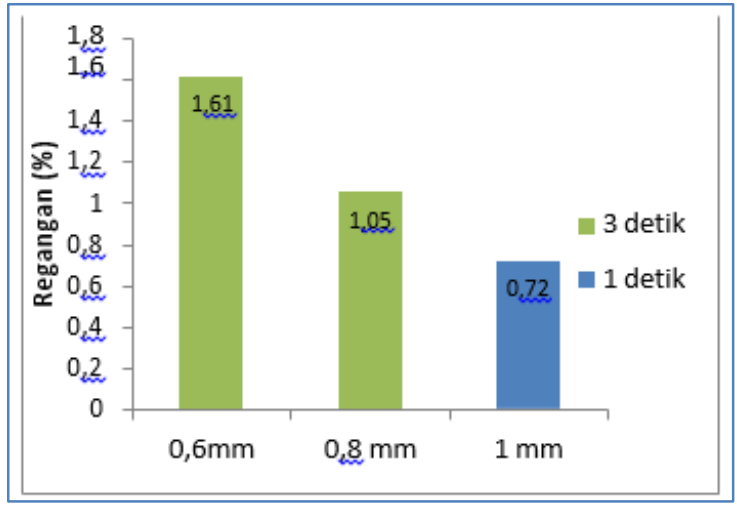

Gambar 12. Grafik pengaruh tebal plat dan waktu tekan terhadap regangan

(elongation) sambungan las titik.

Pada grafik tersebut diatas dapat dilihat bahwa regangan yang terjadi paling besar ada pada plat dengan tebal 0,6 mm adalah waktu tekan 3 detik dengan nilai regangan $1,61 \%$, plat dengan tebal 0,8 $\mathrm{mm}$ adalah waktu tekan 3 detik dengan nilai tegangan $1,05 \%$ dan plat dengan tebal $1 \mathrm{~mm}$ adalah waktu tekan 1 detik dengan nilai tegangan $0,72 \%$.Nilai-nilai regangan tersebut menunjukkan bahwa untuk plat dengan tebal $1 \mathrm{~mm}$ nilai regangannya berbeda dengan plat dngan tebal $0,6 \mathrm{~mm}$ dan $0,8 \mathrm{~mm}$. Regangan merupakan perubahan relatif ukuran atau bentuk suatu material bahan atau logam akibat mengalami tegangan.

\section{KESIMPULAN}

Dari penelitian pengaruh ketebalan plat dan lama penekanan pada pengelasan titik (spot welding) baja karbon rendah terhadap kekuatan tarik diperoleh hasil sebagai berikut:

1. Pengaruh ketebalan dan lama waktu penekanan pada sambungan las dengan menggunakan las titik (spot welding) didapatkan perbedaan nilai kekuatan tarik yaitu:

- Untuk plat dengan ketebalan 0,6 mm,nilai kekuatan tarik terbesar pada waktu tekan 3 detik dengan nilai $67,69 \mathrm{~N} / \mathrm{mm}^{2}$ dan nilai kekuatan tarik terendah pada waktu tekan 1 detik dengan nilai 28,36 $\mathrm{N} / \mathrm{mm}^{2}$.

- Untuk plat dengan ketebalan 0,8 
mm, nilai kekuatan tarik terbesar pada waktu tekan 3 detik dengan nilai $38,78 \mathrm{~N} / \mathrm{mm}^{2}$ dan nilai kekuatan tarik terendah pada waktu tekan 1 detik dengan nilai $28 \mathrm{~N} / \mathrm{mm}^{2}$.

- Untuk plat dengan ketebalan $1 \mathrm{~mm}$, nilai kekuatan tarik terbesar pada waktu tekan 1 detik dengan nilai $13,79 \mathrm{~N} / \mathrm{mm}^{2}$ dan nilai kekuatan tarik terendah pada waktu tekan 3 detik dengan nilai 11,25 $\mathrm{N} / \mathrm{mm}^{2}$.

2. Ketebalan dan waktu penekanan sangatlah berpengaruh terhadap kekuatan hasil lasan pada proses pengelasan titik (spot welding). Namun untuk pengujian plat dengan tebal 1 $\mathrm{mm}$ hasilnya berbanding terbalik dengan hasil pada plat dengan tebal 0,6 $\mathrm{mm}$ dan $0,8 \mathrm{~mm}$.

3. Berdasarkan dari hasil pengujian, sambungan lap joint yang paling optimum yaitu:

- Untuk plat dengan ketebalan 0,6 mm menggunakan waktu tekan 3 detik.

- Untuk plat dengan ketebalan 0,8 mm menggunakan waktu tekan 3 detik.

- Untuk plat dengan ketebalan 1 mm menggunakan waktu tekan 1 detik.

\section{REFERENSI}

[1]. Wiryosumarto, H \& Teshi Okumura. 1991."Teknik Pengelasan Logam". Cetakankedelapan. Jakarta : PT Pradnya Paramita.

[2]. Tata Surdia, Shinrokku Saito. 1992. "pengetahuan bahan teknik", cetakan kedua. Jakarta : PT Pradnya Paramita.

[3]. JIS Hand Book (1986), Ferrous Materials and Metallurgy, Japanese Standart Association, Akasaka 4Chome, Minato- ku, Tokyo.
[4]. Laboratorium Teknik Sipil Universitas Bandar Lampung, J1. Zainal Abidin Pagar Alam No. 26, Labuhan Ratu, Kedaton, Kota Bandar Lampung, Lampung.

[5]. Anrinal \& Hendri, 2012, Analisa kekuatan tarik hasil spot welding baja karbon rendah. Jurnal teknik mesin Vol. 1, No. 2.

[6]. Smith, F.J.M. (1992). Basic fabrication and welding engineering, Hong Kong: Wing Tai Cheung Printing Co. Ltd.

[7]. PEREIRA AM., dkk., 2012, Effect of Process Parameters on the Strength of Resistance Spot Welds in 6082-T6 Aluminium Alloy, Material and Design 31, Elsevier. 